\title{
Prevalence and risk factors for CTX-M gram-negative bacteria in hospitalized patients at a tertiary care hospital in Kilimanjaro, Tanzania
}

\author{
Tolbert Sonda $^{1,2} \cdot$ Happiness Kumburu ${ }^{1,2} \cdot$ Marco van Zwetselaar ${ }^{1} \cdot$ Michael Alifrangis $^{3,4} \cdot$ Blandina T. Mmbaga $^{1,2}$. \\ Ole Lund ${ }^{5} \cdot$ Frank M. Aarestrup $^{6} \cdot$ Gibson Kibiki $^{2,7}$
}

Received: 23 November 2017 / Accepted: 18 January 2018 / Published online: 20 February 2018

(C) The Author(s) 2018. This article is an open access publication

\begin{abstract}
Emergence and spread of extended spectrum beta-lactamase (ESBL)-producing gram-negative bacteria, mainly due to CTX-M, is a major global public health problem. Patients infected with ESBL-producing gram-negative bacteria have an increased risk of treatment failure and death. We investigated the prevalence and risk factors for CTX-M gram-negative bacteria isolated from clinical specimens of patients hospitalized at a tertiary care hospital in Kilimanjaro, Tanzania. Isolated gram-negative bacteria from inpatients admitted at Kilimanjaro Christian Medical Centre (KCMC) between August 2013 and August 2015 were fully genome sequenced. The prevalence of ESBL-producing gram-negative bacteria was determined based on the presence of $b l a_{\mathrm{CTX}-\mathrm{M}}$. The odds ratio $(\mathrm{OR})$ and risk factors for ESBL-producing gramnegative bacteria due to CTX-M were assessed using logistic regression models. The overall CTX-M prevalence $(95 \%$ CI) was 13.6\% (10.1-18.1). Adjusted for other factors, the OR of CTX-M gram-negative bacteria for patients previously hospitalized was $0.26(0.08-0.88), p=0.031$; the OR for patients currently on antibiotics was 4.02 (1.29-12.58), $p=$ 0.017; the OR for patients currently on ceftriaxone was $0.14(0.04-0.46), p=0.001$; and the OR for patients with wound infections was $0.24(0.09-0.61), p=0.003$. The prevalence of ESBL-producing gram-negative bacteria due to CTX-M in this setting is relatively low compared to other previous reports in similar settings. However, to properly stop further spread in the hospital, we recommend setting up a hospital surveillance system that takes full advantage of the available next-generation sequencing facility to routinely screen for all types of bacterial resistance genes.
\end{abstract}

Keywords ESBL $\cdot$ Gram-negative bacteria $\cdot$ Prevalence $\cdot$ CTX-M $\cdot$ Whole genome sequencing $\cdot$ Tanzania

Tolbert Sonda

t.sonda@kcri.ac.tz

Happiness Kumburu

h.kumburu@kcri.ac.tz

Marco van Zwetselaar

zwets@kcri.ac.tz

Michael Alifrangis

micali@ sund.ku.dk

Blandina T. Mmbaga

b.mmbaga@kcri.ac.tz

Ole Lund

lund@cbs.dtu.dk

Frank M. Aarestrup

fmaa@food.dtu.dk
Gibson Kibiki

g.kibiki@gmail.com

1 Kilimanjaro Christian Medical Centre, Kilimanjaro Clinical Research Institute, Moshi, Tanzania

2 Kilimanjaro Christian Medical University College, Moshi, Tanzania

3 Centre for Medical Parasitology, Department of Immunology and Microbiology, University of Copenhagen, Copenhagen, Denmark

4 Department of Infectious Diseases, Copenhagen University Hospital, Copenhagen, Denmark

5 Centre for Biological Sequence Analysis, Technical University of Denmark, Lyngby, Denmark

6 DTU-Food, Centre for Genomic Epidemiology, Technical University of Denmark, Lyngby, Denmark

7 East African Health Research Commission, Bujumbura, Burundi 


\section{Introduction}

Existence of antibiotic resistance due to extended spectrum beta-lactamase (ESBL)-producing gram-negative bacteria is a major global public health problem [1] and has been reported in all regions of the world [2-7]. Compared to patients infected with beta-lactam susceptible bacteria, patients infected with ESBL-producing gram-negative bacteria put a greater burden on health-care resources and have an increased risk of treatment failure and poor outcomes including death $[8,9]$. High-income countries (HICs) have surveillance systems in place to estimate the burden of bacterial infections due to ESBL-producing gram-negative bacteria, and to determine risk factors for acquisition of ESBL-producing gram-negative bacteria as well as the clinical outcomes associated with infection [1, 10-12]. In Sub-Sahara Africa (SSA), data on ESBLproducing gram-negative bacteria epidemiology and risk factors associated with ESBL-producing gram-negative bacteria infection are scarce. When available, the data mostly originates from hospital-based studies [13-18]. Several risk factors have been documented to be associated with ESBL-producing gram-negative bacteria acquisition, including previous hospitalization, previous use of antibiotics such as third-generation cephalosporins, hospital overcrowding, bed sharing when hospitalized, and international travel [19-25].

In 2002, Blomberg et al. reported high proportions of infections due to ESBL-producing gram-negative bacteria at the National Hospital in Dar es Salaam, Tanzania [26]. Since then, other reports have shown an increasing trend of ESBLproducing gram-negative bacteria infections in the same hospital [14, 27-29]. Similarly, studies conducted at a tertiary hospital in Mwanza, Tanzania have documented an increase in ESBL-producing gram-negative bacteria infections [28, 30, 31]. Like the centers in Dar es Salaam and Mwanza, Kilimanjaro Christian Medical Centre (KCMC) is a major zonal tertiary healthcare facility, serving nearly one quarter of Tanzania's estimated 53.5 million inhabitants [32]. Its setting however sets KCMC apart: the Kilimanjaro region in Tanzania has among the highest international movements of people in the country for tourism and business. The region has four distinct ecosystems inhabited by diverse communities of miners, pastoralists, agrarians, and fishermen. Given the public health importance of ESBL-producing gram-negative bacteria, the role that KCMC plays in guiding empirical treatment, and the need for therapeutic decisions to be based on guidelines which are derived from local epidemiological data [33], a study on ESBL-producing gram-negative bacteria in $\mathrm{KCMC}$ was found to be imperative. In our setting, little attention is paid to gram-negative bacteria, although they have been reported in east Africa and elsewhere to be causes of outbreaks and to be main contributors of ESBL resistance due to production of CTX-M $[13,34]$. The aim of this study was to determine the proportion estimates and risk factors for
ESBL-producing gram-negative bacteria due to CTX-M using whole genome sequences of all gram-negative bacteria isolated from clinical specimens at KCMC hospital.

\section{Materials and methods}

\section{Study design, participants, and specimen collection}

A hospital-based cross-sectional study was conducted at KCMC between August 2013 and August 2015. Geographically, $\mathrm{KCMC}$ is located in north-eastern Tanzania and serves as a zonal referral hospital. The hospital has a bed capacity of 650 with approximately 500 outpatients seeking medical services daily.

The study involved patients admitted in medical, surgical, and pediatrics wards who were suspected to have bacterial infection. A written consent was obtained from each participant or from parents or guardians of children before enrolment into the study. Clinical specimens collected for bacterial culture were sputum, wound or pus swab, stool, and blood.

\section{Bacterial culture and identification}

Bacteria culture, isolation, and identification were performed according to in-house standard operating procedures as well as the Clinical and Laboratory Standards Institute (CLSI) guidelines as described by Kumburu et al. [35].

\section{Genomic DNA isolation, whole genome sequencing, and analysis}

Bacterial genomic DNA (gDNA) was purified and its concentration determined using the Easy-DNA extraction kit Invitrogen ${ }^{\circledR}$ and the Qubit dsDNA Assay Kit Invitrogen ${ }^{\circledR}$ respectively. The gDNA library preparation was performed following Nextera ${ }^{\circledR}$ XT DNA Sample Preparation Guide [36]. In brief, each gDNA was tagmented (tagged and fragmented) by the Nextera ${ }^{\circledR}$ XT transposome. The transposome simultaneously fragments the input DNA and adds adapter sequences to the ends. Thereafter followed a limited-cycle PCR amplification whereby indexes required for cluster formation were added to each DNA piece. Then each gDNA library was normalized to ensure equal representation during sequencing. Equal volumes of the normalized library were combined, diluted in hybridization buffer, and heat-denatured prior to sequencing on the Illumina MiSeq platform (Illumina, Inc., San Diego, CA). Whole genome sequence reads were analyzed using bioinformatics tools available on https://cge.cbs.dtu.dk/services/. For this report's purpose, the analyses included de novo reads assembly, species identification, and determination of $b l a_{\text {СтХ-М }}$ encoding ESBL. 


\section{Collection of metadata and statistical analyses}

Case report and laboratory result forms designed for this study were used to collect metadata. Double data entry was performed in OpenClinica (OpenClinica LLC, MA USA). Stata version 13 (StataCorp LP, Texas 77845 USA) was used for all statistical analyses. The prevalence of resistance due to ESBLproducing gram-negative bacteria was calculated as the number of gram-negative bacteria positive for $b l a_{\text {СТХ-M }}$ divided by total number of gram-negative bacteria sequenced. The prevalence across levels of a categorical variable, such as age, gender, wards admitted, type of bed, hospitalization, antibiotics use, disease conditions, and comorbidities, was compared using Chi-square test or Fisher's exact test. Logistic regression was performed to determine risks of isolating CTX-M gram-negative bacteria strains from patients. In the multivariate analysis, we included any variable whose $p$ value $\leq 10 \%$ and those that were considered key risk factors regardless of their $p$ values being $>10 \%$ in univariate analysis. Statistical significance of associations was decided based on a two-tailed $p$ value and respective $95 \%$ confidence intervals.

\section{Results}

\section{Study population}

In total, 575 patients were included in this study (Table 1). These baseline data have also been presented before by Kumburu et al. [35]. The median age in years (IQR) was 43 $(30-57)$, and $348(60.6 \%)$ of the patients were males. Three hundred thirty nine $(59.2 \%)$ had primary education level and $271(47.3 \%)$ were farmers. A total of $301(52.3 \%)$ patients were admitted into medical wards. One hundred six (18.4\%) of all patients were on stretcher type beds. A total of 287 (49.9\%) specimens were wound and/or pus swabs.

A total of $263(45.9 \%)$ patients had infected wounds, 81 (14.1\%) had pneumonia, and $20(3.5 \%)$ had diarrhea. A total of $60(10.5 \%)$ were TB, 81(14.1\%) were HIV, and 122 $(21.3 \%)$ were diabetic cases. Out of all participants, 412 (71.9\%) were on antibiotics at the time specimens were collected (Table 1).

\section{Prevalence of CTX-M in gram-negative bacteria}

A total of 590 specimens were collected in the following distribution: 56 were stool, 122 were sputum, 126 were blood, and 286 were wound or pus swabs. Of all the specimens, 249 were culture-positive yielding 377 bacterial isolates that were fully sequenced. Of these, 287 bacterial isolates were gramnegative bacteria. The most prevalent gram-negative bacteria were Proteus spp. $(n=48,16.7 \%)$, Escherichia coli $(n=44$, $15.3 \%)$, Pseudomonas spp. $(n=40,13.9 \%)$, and Klebsiella
Table 1 Demographic and clinical characteristics of the study population

\begin{tabular}{|c|c|}
\hline Patient characteristic & Total \\
\hline Number of patients & $575(100)$ \\
\hline Median age in years (IQR) & $43(30-57)$ \\
\hline \multicolumn{2}{|l|}{ Gender } \\
\hline Female & $226(39.4)$ \\
\hline Male & $348(60.6)$ \\
\hline \multicolumn{2}{|l|}{ Occupation } \\
\hline Farming & $271(47.3)$ \\
\hline Employed & $177(30.9)$ \\
\hline Other & $125(21.8)$ \\
\hline \multicolumn{2}{|l|}{ Education level } \\
\hline No & $130(22.7)$ \\
\hline Primary & $339(59.2)$ \\
\hline Secondary/Above & $104(18.2)$ \\
\hline \multicolumn{2}{|l|}{ Ward of admission } \\
\hline Surgical & $257(44.7)$ \\
\hline Medical & $301(52.3)$ \\
\hline Other & $17(3.0)$ \\
\hline \multicolumn{2}{|l|}{ Location of patient } \\
\hline In Corridor/Stretcher & $106(18.4)$ \\
\hline Inside room/Bed & $469(81.6)$ \\
\hline \multicolumn{2}{|l|}{ Specimen collected } \\
\hline Blood & $117(20.3)$ \\
\hline Sputum & $120(20.9)$ \\
\hline Stool & $51(8.9)$ \\
\hline Swabs (wound or pus) & $287(49.9)$ \\
\hline \multicolumn{2}{|l|}{ Comorbid conditions } \\
\hline Wound & $263(45.9)$ \\
\hline Pneumonia & $81(14.1)$ \\
\hline Tuberculosis & $60(10.5)$ \\
\hline Sepsis, septicemia & $113(19.7)$ \\
\hline Diarrhea & $20(3.5)$ \\
\hline Diabetes & $122(21.3)$ \\
\hline HIV & $81(14.1)$ \\
\hline Cancer & $52(9.1)$ \\
\hline Currently on antibiotics & $412(71.9)$ \\
\hline
\end{tabular}

spp. $(n=38,13.2 \%)$. The CTX-M gene was found in 39 of the 287 gram-negative bacteria, yielding an overall prevalence (95\% CI) of $13.6 \%$ (10.1-18.1) (Table 2). The prevalence in isolates from those admitted in surgical, medical, and ICU wards, respectively, were $5.0 \%$ (2.5-9.8), 9.4\% (4.7-17.8), and $3.1 \%(0.4-19.8)$. Table 2 shows also crude odds ratios (OR) for different patient characteristics. The crude OR (95\% CI) of CTX-M gram-negative bacteria in patients admitted in medical wards was significantly higher compared to those from surgical wards; OR 3.62 (1.74-7.52), $p=0.001$. Bacterial isolates from those sleeping in ward corridors/ 
Table 2 Socio-demographic characteristics of patients from which CTX-M gram-negative bacteria were isolated

\begin{tabular}{|c|c|c|c|}
\hline \multirow[t]{2}{*}{ Patient characteristics } & \multicolumn{3}{|c|}{ CTX-M gram-negative bacteria } \\
\hline & Prevalence $(95 \% \mathrm{CI})$ & Crude OR $(95 \% \mathrm{CI})$ & $P$ value \\
\hline All CTX-M & $13.6(10.1-18.1)$ & - & - \\
\hline \multicolumn{4}{|l|}{ Age (years) } \\
\hline $0-35(n=87)$ & $4.6(1.7-11.7)$ & 1 (Ref) & - \\
\hline $36-53(n=84)$ & $6.0(2.5-13.6)$ & $1.27(0.53-3.01)$ & 0.595 \\
\hline 54 and above $(n=100)$ & $8.0(4.0-15.3)$ & $1.12(0.48-2.63)$ & 0.786 \\
\hline \multicolumn{4}{|l|}{ Department $^{\mathrm{a}}$} \\
\hline $\mathrm{SW}(n=159)$ & $5.0(2.5-9.8)$ & 1 (Ref) & - \\
\hline MW $(n=85)$ & $9.4(4.7-17.8)$ & $3.62(1.74-7.52)$ & 0.001 \\
\hline $\mathrm{ICU}(n=32)$ & $3.1(0.4-19.8)$ & $0.69(0.15-3.20)$ & 0.636 \\
\hline \multicolumn{4}{|l|}{ Hospital stay (days) } \\
\hline $0-4(n=82)$ & $7.3(3.3-15.5)$ & 1 (Ref) & - \\
\hline $5-12(n=91)$ & $6.6(3.0-14.0)$ & $1.05(0.47-2.36)$ & 0.911 \\
\hline 13 and above $(n=86)$ & $3.5(1.1-10.4)$ & $0.47(0.18-1.25)$ & 0.129 \\
\hline \multicolumn{4}{|l|}{ Gender } \\
\hline Female $(n=111)$ & $4.5(1.9-10.4)$ & 1 (Ref) & - \\
\hline Male $(n=166)$ & $7.2(4.1-12.3)$ & $0.91(0.45-1.82)$ & 0.783 \\
\hline \multicolumn{4}{|l|}{ History of hospitalization } \\
\hline No $(n=188)$ & $6.4(3.6-10.9)$ & 1 (Ref) & - \\
\hline Yes $(n=99)$ & $5.1(2.1-11.7)$ & $0.53(0.24-1.16)$ & 0.111 \\
\hline \multicolumn{4}{|l|}{ History of medication } \\
\hline No $(n=109)$ & $3.7(1.4-9.4)$ & 1 (Ref) & - \\
\hline Yes $(n=178)$ & $7.3(4.3-12.2)$ & $1.26(0.62-2.58)$ & 0.521 \\
\hline \multicolumn{4}{|l|}{ Current medication } \\
\hline No $(n=81)$ & $8.6(4.1-17.2)$ & 1 (Ref) & - \\
\hline Yes $(n=206)$ & $4.9(2.6-8.8)$ & $1.0(0.47-2.12)$ & 0.998 \\
\hline \multicolumn{4}{|l|}{ Patient location } \\
\hline Inside room/Beds $(\mathrm{n}=166)$ & $4.8(2.4-9.4)$ & 1 (Ref) & - \\
\hline Corridor/Stretcher $(n=121)$ & $7.4(3.9-13.7)$ & $0.94(0.48-1.88)$ & 0.877 \\
\hline
\end{tabular}

${ }^{\text {a }} s w$ surgical ward, $m w$ medical ward, $I C U$ intensive care unit stretchers had a prevalence of $7.4 \%$ (3.9-13.7), versus $4.8 \%$ (2.4-9.4) for those sleeping inside rooms/beds (Table 2). Prevalence of ESBL-producing gram-negative bacteria due to CTX-M per different disease conditions was investigated (Table 3). Among patients with wound infections, the prevalence was $4.2 \%(2.0-8.6)$ while among diarrhea cases, TB cases, and patients with sepsis, the prevalence was $2.0 \%$ (4.6-56.3), 6.7\% (0.9-37.1), and 2.9\% (0.7-11.3), respectively. Furthermore, ESBL-producing gram-negative bacteria prevalence due to CTX-M in HIV and in diabetic cases was $11.1 \%(3.5-30.0)$ and $8.5 \%$ (3.8-17.7), respectively.

Table 3 further documents crude ORs for different morbidities. Crude OR of CTX-M gram-negative bacteria in patients with wounds was significantly lower compared to those who did not have wounds; OR $0.28(0.14-0.58), p=0.001$, while the crude OR of CTX-M gram-negative bacteria in patients with diarrhea was significantly higher compared to those without; OR 11.0 (2.94-40.98), $p=0.001$. The trend for OR of infection with CTX-M gram-negative bacteria among HIV cases was higher compared to non-HIV cases; OR 2.46 (0.96-6.30), $p=0.06$.

We also investigated the prevalence of CTX-M gram-negative bacteria in patients on different antibiotics (Table 4). The prevalence of CTX-M gram-negative bacteria in patients on at least one antibiotic was 6.8\% (4.1-10.9). The OR of CTX-M gram-negative bacteria when patients were on other Ceftriaxone as compared to those who were not showed that those on Ceftriaxone had a reduced risk; OR 0.34 (0.16-0.71), $p=0.004$, while there was a trend that those on Ciprofloxacin had an increased risk of CTX-M gram-negative bacteria; OR $2.62(0.88-7.83), p=0.084$.

\section{Risk factors for CTX-M gram-negative bacteria}

Table 5 shows adjusted OR (AOR) for various patient characteristics. After adjusting for other patient characteristics, 
Table 3 Morbidity types and prevalence of CTX-M gramnegative bacteria

\begin{tabular}{|c|c|c|c|}
\hline \multirow[t]{2}{*}{ Patient characteristics } & \multicolumn{3}{|c|}{ CTX-M gram-negative bacteria } \\
\hline & Prevalence $(95 \% \mathrm{CI})$ & Crude OR $(95 \% \mathrm{CI})$ & $P$ value \\
\hline \multicolumn{4}{|l|}{ Infected wounds } \\
\hline No $(n=109)$ & $9.2(4.9-16.3)$ & 1 (Ref) & - \\
\hline Yes $(n=167)$ & $4.2(2.0-8.6)$ & $0.28(0.14-0.58)$ & 0.001 \\
\hline \multicolumn{4}{|l|}{ Pneumonia } \\
\hline No $(n=261)$ & $6.1(3.8-9.8)$ & 1 (Ref) & - \\
\hline Yes $(n=15)$ & $6.7(0.9-37.1)$ & $1.61(0.43-6.01)$ & 0.475 \\
\hline \multicolumn{4}{|l|}{ Tuberculosis } \\
\hline No $(n=261)$ & $6.1(3.8-9.8)$ & 1 (Ref) & - \\
\hline Yes $(n=15)$ & $6.7(0.9-37.1)$ & $0.96(0.21-4.44)$ & 0.96 \\
\hline \multicolumn{4}{|l|}{ Sepsis } \\
\hline No $(n=220)$ & $6.8(4.1-11.0)$ & 1 (Ref) & - \\
\hline Yes $(n=67)$ & $2.9(0.7-11.3)$ & $0.56(0.22-1.39)$ & 0.211 \\
\hline \multicolumn{4}{|l|}{ Diarrhea } \\
\hline No $(n=266)$ & $5.6(3.4-9.2)$ & 1 (Ref) & - \\
\hline Yes $(n=10)$ & $2.0(4.6-56.3)$ & $10.97(2.94-40.98)$ & 0.001 \\
\hline \multicolumn{4}{|l|}{ Diabetes } \\
\hline No $(n=205)$ & $5.4(2.9-9.5)$ & 1 (Ref) & - \\
\hline Yes $(n=71)$ & $8.5(3.8-17.7)$ & $1.04(0.48-2.26)$ & 0.928 \\
\hline \multicolumn{4}{|l|}{ HIV } \\
\hline No $(n=249)$ & $5.6(3.3-9.3)$ & 1 (Ref) & - \\
\hline Yes $(n=27)$ & $11.1(3.5-30.0)$ & $2.46(0.96-6.30)$ & 0.06 \\
\hline
\end{tabular}

several variables appeared to be statistically associated with CTX-M gram-negative bacteria. These variables include prior admission, currently on antibiotics, currently on ceftriaxone, and wound infections. Those with a prior admission history
Table 4 Antibiotic use and prevalence of CTX-M in gramnegative bacteria

\begin{tabular}{|c|c|c|c|}
\hline \multirow[t]{2}{*}{ Patient characteristics } & \multicolumn{3}{|c|}{ CTX-M gram-negative bacteria } \\
\hline & Prevalence $(95 \% \mathrm{CI})$ & Crude OR (95\% CI) & $P$ value \\
\hline \multicolumn{4}{|l|}{ Currently on antibiotics } \\
\hline No $(n=54)$ & $3.7(0.9-13.9)$ & 1 (Ref) & - \\
\hline Yes $(n=222)$ & $6.8(4.1-10.9)$ & $1.35(0.53-3.41)$ & 0.529 \\
\hline \multicolumn{4}{|l|}{ Ciprofloxacin } \\
\hline No $(n=258)$ & $6.2(3.8-9.9)$ & 1 (Ref) & - \\
\hline Yes $(n=18)$ & $5.6(0.7-32.1)$ & $2.62(0.88-7.83)$ & 0.084 \\
\hline \multicolumn{4}{|l|}{ Ceftriaxone } \\
\hline No $(n=135)$ & $8.1(4.5-14.2)$ & 1 (Ref) & - \\
\hline Yes $(n=141)$ & $4.3(1.9-9.2)$ & $0.34(0.16-0.71)$ & 0.004 \\
\hline \multicolumn{4}{|l|}{ Cotrimoxazole } \\
\hline No $(n=267)$ & $6.0(3.7-9.6)$ & 1 (Ref) & - \\
\hline Yes $(n=9)$ & $11.1(1.3-53.4)$ & $3.31(0.79-13.86)$ & 0.101 \\
\hline \multicolumn{4}{|l|}{ Cloxacillin } \\
\hline No $(n=216)$ & $6.0(3.5-10.1)$ & 1 (Ref) & - \\
\hline Yes $(n=60)$ & $6.6(2.5-16.6)$ & $0.64(0.25-1.61)$ & 0.342 \\
\hline \multicolumn{4}{|l|}{ Metronidazole } \\
\hline No $(n=256)$ & $5.9(3.2-10.7)$ & 1 (Ref) & - \\
\hline Yes $(n=20)$ & $6.5(3.1-13.1)$ & $1.63(0.52-5.17)$ & 0.405 \\
\hline
\end{tabular}


Table 5 Multivariate logistic regression model showing adjusted ORs for isolating CTX-M gram-negative bacteria

\begin{tabular}{lll}
\hline Patient characteristics & AOR $^{\mathrm{a}}(95 \% \mathrm{CI})$ & $P$ value \\
\hline Prior admission & $0.26(0.08-0.88)$ & 0.031 \\
Prior medication & $1.50(0.62-3.62)$ & 0.368 \\
Currently admitted in surgical ward & $0.70(0.28-1.76)$ & 0.444 \\
Patient inside the room & $0.76(0.32-1.78)$ & 0.522 \\
Over 4 days of hospitalization & $0.72(0.31-1.71)$ & 0.462 \\
Currently on antibiotic & $4.02(1.29-12.58)$ & 0.017 \\
Currently on Ciprofloxacin & $0.84(0.21-3.35)$ & 0.804 \\
Currently on Ceftriaxone & $0.14(0.04-0.46)$ & 0.001 \\
HIV positive & $1.15(0.37-3.55)$ & 0.804 \\
Wound infection & $0.24(0.09-0.61)$ & 0.003 \\
\hline
\end{tabular}

${ }^{\text {a }}$ Adjusted odds ratio

showed a relatively reduced risk of CTX-M gram-negative bacteria compared to those with no prior history of admission; AOR $0.26(0.08-0.88), p=0.031$. An increased risk of CTX$\mathrm{M}$ gram-negative bacteria was observed for those currently on at least one antibiotic compared to those who were not on any antibiotics; AOR 4.02 (1.29-12.58), $p=0.017$. A decreased risk of CTX-M gram-negative bacteria was observed among those who were currently on Ceftriaxone compared to those who were not on Ceftriaxone; AOR 0.14(0.04-0.46), $p=$ 0.001 and for those with wound infections was 0.24 ( 0.09 $0.61), p=0.003$. There is also seen a lower likelihood in patients with wound infection than those without wound infections.

\section{Discussion}

This survey investigated the prevalence and possible risk factors for CTX-M gram-negative bacteria in hospitalized patients in Kilimanjaro, Tanzania. It is the first report to investigate ESBL-producing gram-negative bacteria due to CTX-M in clinical specimens using whole genome sequencing and not based on phenotypic testing. To the best of our knowledge, it is the first risk factor analysis of ESBL-producing gram-negative bacteria infections in Tanzania. The overall prevalence of CTX-M gram-negative bacteria in this study was $13.6 \%$. This hospital-study's findings are comparable with other hospital studies that had previously reported low ESBLproducing gram-negative bacteria prevalence in Gabon, $15.0 \%$ [37], and Central Africa Republic, 4 to $19 \%$ [38]. However, the report's prevalence contrasts with $42 \%$ prevalence in a review on general ESBL-producing gram-negative bacteria in East Africa hospitals [34], a 29.7\% prevalence previously reported in Kilimanjaro by Kajeguka et al. [39], and $32.6 \%$ prevalence reported in Guinea-Bissau [22]. Further, our findings contrast with other reports on ESBL- producing gram-negative bacteria in hospitals outside the East African region in that they had shown higher prevalence than in this report: Cameroon 55\% [19], Ghana 49\% [23], Egypt above 45\% [40], and South Africa 83\% [41]. There could be several reasons for the observed low prevalence (13.6\%) of CTX-M gram-negative bacteria, including the fact that the majority of patients were sampled while they had been on antibiotics for a number of days since admission. The prevalence of CTX-M gram-negative bacteria was observed to decrease with hospitalization days. The use of ceftriaxone in the majority of inpatients at $\mathrm{KCMC}$ is a plausible explanation for the observed low prevalence of CTX-M, and the decrease in prevalence over time. Moreover, the prevalence of CTX-M at admission may be relatively high due to selection of ESBLproducing gram-negative bacteria in the community due to overuse of antibiotics other than ceftriaxone. A comparison of CTX-M resistance between patients on ceftriaxone versus patients on other cephalosporins like ceftazidime or cefepime would have been of great interest; however, the available data was insufficient for this analysis.

Prevalence of CTX-M gram-negative bacteria appeared to increase with age. The numbers of patients with age more than 65 years in this study were low, so the comparison with other publications could not be done. Other reports [42-44] have shown adults over 65 to be almost three times at risk of infection with ESBL-producing gram-negative bacteria. Due to their diminishing immunity and repeated hospitalization, this group is more prone to infections including resistant bacterial strains. However, there appears to be no statistical evidence to support the observed proportion differences in the risks of the CTX-M gram-negative bacteria across age groups.

We investigated whether or not sleeping on stretchers and sleeping in corridors as proxy indicators of overcrowding were associated with the CTX-M gram-negative bacteria. It was found that the prevalence of CTX-M gram-negative bacteria in patients sleeping in ward corridors (on stretchers) as the proper beds were all occupied and no space inside the rooms were relatively high compared to their counterparts. However, sleeping on stretchers and sleeping in corridors were not significantly associated with increased risk of isolating CTX-M gram-negative bacteria.

Factors that showed statistically significant associations with CTX-M gram-negative bacteria include prior admission, currently on antibiotics, use of Ceftriaxone, and wound infections. This report shows that a large proportion (71.9\%) of patients was already on antibiotics therapy when specimens were collected for microbiological analyses. Prevalence of isolating CTX-M gram-negative bacteria from patients who were on at least one type of antibiotics was higher $(6.8 \%)$ than in those who were not $(3.7 \%)$. The likelihood of isolating CTX-M gram-negative bacteria from those who were currently on antibiotics was found to be four times higher than from those who were not on 
antibiotics therapy. Reports have shown that the risk of developing antibiotics resistance in societies where antibiotics are excessively used is high $[44,45]$ due to antimicrobial resistance selection pressure. In KCMC, being a referral hospital, the patients coming to seek medical services are those who might have used antibiotics but treatment failed due to carriage of resistant strains prior to their referrals. Furthermore, given the fact that patients are referred to our hospital from different healthcare facilities, the likelihood of patients to have been on antibiotics is high. Self-referred patients rarely have a paper record of prior medications. Empirical therapy, self-medication, and over-the-counter medications are common in low-income countries (LIC) [46-48]. This experience-based therapy practiced by physicians in LIC is one of the factors fuelling emergence of resistance, particularly when unnecessarily switching to higher generations of antibiotics.

Ceftriaxone has been a drug of choice by many physicians in our setting due to its broad-spectrum activity. Over $51 \%$ of the analyzed gram-negative bacteria were isolated from patients who were on Ceftriaxone. The prevalence of CTX-M gram-negative bacteria was $4.3 \%$ from patients who were on Ceftriaxone, compared to $8.1 \%$ for those who were not. The likelihood of isolating CTX-M gramnegative bacteria from those who were currently on Ceftriaxone appeared to be seven times lower than those who were not treated with Ceftriaxone. As self-medication with Ceftriaxone is uncommon due to its high cost, this suggests that treatment with injectable Ceftriaxone in the hospital was effective against CTX-M gram-negative bacteria. Nevertheless, its prescription should be guided by microbiological results.

A substantial proportion (34.5\%) of CTX-M gram-negative bacteria was isolated from patients who had a history of admission (hospitalization). The prevalence of isolating CTX-M gram-negative bacteria from patients with no history of admission (hospitalization) was $6.4 \%$, higher than $5.1 \%$ in those with hospitalization history. However, the likelihood of isolating CTX-M gram-negative bacteria from patients with history of admission was approximately four times lower than their counterparts, consistent with a recent report [49] that showed a 32\% lower risk of ESBLproducing gram-negative bacteria among previously hospitalized patients. It could be that during past admissions, these patients were put on Ceftriaxone doses that had successfully treated CTX-M gram-negative bacteria. This report suggests that Ceftriaxone could be effective against CTX-M gram-negative bacteria. Furthermore, the observed high risk of CTX-M gram-negative bacteria among those who had no prior admission could be explained by the fact that they were carrying resistant CTX-M gram-negative bacteria from the community. However, these findings are different from reports $[20,45,50,51]$ which found that previous admission and use of cephalosporins increase the risk of CTX-M gram-negative bacteria.

A benefit of this study is its contribution to a larger project in which we have been able to build an infrastructure and implement next-generation sequencing (NGS) techniques for clinical diagnostics. For the current report, we have been able to analyze clinical specimens by doing whole genome sequencing to identify CTX-M genes that code for ESBL. We acknowledge that several limitations need to be addressed. Firstly, wound and pus swab specimens make up the majority of samples studied. Microbiology results do not always represent the cause of the infection. Secondly, in this report, ESBLproducing gram-negative bacteria resistance was defined based on the presence of the CTX-M gene. Despite its important role in resistance, this restricted definition means we may have underestimated the ESBL-producing gram-negative bacteria prevalence. Underestimation of ESBL-producing gram-negative bacteria resistance could also be attributed to sampling patients who were already on antibiotics treatment. Thirdly, though our report highlights some key aspects regarding prevalence and risk factors for ESBL-producing gram-negative bacteria resistance due to CTX-M gram-negative bacteria that are important in programming for antimicrobial control, the study was insufficiently powered to confidently draw conclusions about all suspected variables, especially those that appeared contradicting. Fourth, this study was unable to differentiate between community-acquired and hospital-acquired ESBL-producing gram-negative bacteria as clinical sampling was done during, rather than prior to hospitalization. Finally, the widespread use of antibiotics in our settings makes it difficult to ascertain whether or not exposure to antibiotics preceded the emergency of ESBL-producing gram-negative bacteria resistance due to CTX-M.

\section{Conclusions}

In conclusion, although the prevalence of ESBL-producing gram-negative bacteria due to CTX-M in this setting was found to be low, it is worthwhile to devise approaches aimed at containing the situation before it gets out of control. To properly stop their spread in the hospital, apart from direct containment methods, we recommend setting up a hospital surveillance system that takes full advantage of the available NGS facility to routinely screen for other resistant bacterial genes.

Acknowledgements We thank all patients who consented to participate in this study, and the management of Kilimanjaro Christian Medical Centre. We appreciate the efforts of the Data Management team of 
Kilimanjaro Clinical Research Institute, in particular Salim Semvua, Lilian Mboya, and Krisanta Wilhelm who were the data entry clerks.

Availability of data and materials Data are available on request to the authors.

Authors' contributions TS conceived the initial idea. FA, OL, and GK refined the idea. TS and HK performed laboratory analyses. TS and MZ analyzed data and prepared manuscript draft. All authors read, revised, and approved the final manuscript.

Funding This study was supported by DANIDA through Danida Fellowship Centre award number DFC No. 12-007DTU.

\section{Compliance with ethical standards}

Ethical approval and participant's consent This study was granted ethical approval by the KCMC Research Ethics Committee and the National Institute for Medical Research with approval numbers 893 and NIMR/HQ/R.8a/Vol.IX/2080 respectively. A written consent was obtained from each participant or from parents or guardians of children before enrolment into the study.

Competing interests The authors declare that they have no competing interests.

Open Access This article is distributed under the terms of the Creative Commons Attribution 4.0 International License (http:// creativecommons.org/licenses/by/4.0/), which permits unrestricted use, distribution, and reproduction in any medium, provided you give appropriate credit to the original author(s) and the source, provide a link to the Creative Commons license, and indicate if changes were made.

\section{References}

1. World Health Organization (WHO) (2014) Antimicrobial resistance: global report on surveillance http://www.who.int/ drugresistance/documents/surveillancereport/en/. Accessed 5 Apr 2016

2. Souverein D, Euser SM, Herpers BL, Diederen B, Houtman P, van Seventer $M$ et al (2016) Prevalence, risk factors and molecular epidemiology of highly resistant gram negative rods in hospitalized patients in the Dutch region Kennemerland. Antimicrobial Resistance \& Infection Control 5:1-10. https://doi.org/10.1186/ s13756-016-0107-6

3. Mehrgan H, Rahbar M (2008) Prevalence of extended-spectrum beta-lactamase-producing Escherichia coli in a tertiary care hospital in Tehran, Iran. Int J Antimicrob Agents 31:147-151. https://doi. org/10.1016/j.ijantimicag.2007.09.008

4. Zhang J, Zheng B, Zhao L, Wei Z, Ji J, Li L et al (2014) Nationwide high prevalence of CTX-M and an increase of CTX-M-55 in Escherichia coli isolated from patients with community-onset infections in Chinese county hospitals. BMC Infect Dis 14:659. https:// doi.org/10.1186/s12879-014-0659-0

5. Castanheira M, Farrell SE, Krause KM, Jones RN, Sader HS (2014) Contemporary diversity of $\beta$-lactamases among Enterobacteriaceae in the nine U.S. census regions and ceftazidime-avibactam activity tested against isolates producing the most prevalent $\beta$-lactamase groups. Antimicrob Agents Chemother 58:833-838. https://doi. org/10.1128/AAC.01896-13
6. Karabay O, Altindis M, Koroglu M, Karatuna O, Aydemir ÖA, Erdem AF (2016) The carbapenem-resistant Enterobacteriaceae threat is growing: NDM-1 epidemic at a training hospital in Turkey. Ann Clin Microbiol Antimicrob 15:6. https://doi.org/10. 1186/s12941-016-0118-4

7. Sid Ahmed MA, Bansal D, Acharya A, Elmi AA, Hamid JM, Sid Ahmed AM et al (2016) Antimicrobial susceptibility and molecular epidemiology of extended-spectrum beta-lactamase-producing Enterobacteriaceae from intensive care units at Hamad Medical Corporation. Qatar Antimicrobial resistance and infection control 5:4. https://doi.org/10.1186/s13756-016-0103-x

8. Esteve-Palau E, Solande G, Sánchez F, Sorlí L, Montero M, Güerri $\mathrm{R}$ et al (2015) Clinical and economic impact of urinary tract infections caused by ESBL-producing Escherichia coli requiring hospitalization: a matched cohort study. The Journal of infection 71:667674. https://doi.org/10.1016/j.jinf.2015.08.012

9. Maslikowska JA, Walker SAN, Elligsen M, Mittmann N, Palmay L, Daneman N et al (2016) Impact of infection with extendedspectrum $\beta$-lactamase-producing Escherichia coli or Klebsiella species on outcome and hospitalization costs. The Journal of hospital infection 92:33-41. https://doi.org/10.1016/j.jhin.2015.10.001

10. Muellner P, Pleydell E, Pirie R, Baker MG, Campbell D, Carter PE et al (2013) Molecular-based surveillance of campylobacteriosis in New Zealand-from source attribution to genomic epidemiology. Euro Surveillence 18:1-7

11. Bathoorn E, Friedrich AW, Zhou K, Arends JP, Borst DM, Grundmann H, et al (2013) Latent introduction to the Netherlands of multiple antibiotic resistance including NDM-1 after hospitalisation in Egypt, August 2013. Euro Surveill. https://doi. org/10.2807/1560-7917.ES2013.18.42.20610

12. Knetsch C, Lawley T, Hensgens M, Corver J, Wilcox M, Kuijper E (2013) Current application and future perspectives of molecular typing methods to study Clostridium difficile infections. Euro Surveill 18(4). Available online: http://www.eurosurveillance.org/ ViewArticle.aspx?ArticleId=20381

13. Mshana SE, Hain T, Domann E, Lyamuya EF, Chakraborty T, Imirzalioglu C (2013) Predominance of Klebsiella pneumoniae ST14 carrying CTX-M-15 causing neonatal sepsis in Tanzania. BMC Infect Dis 13:466. https://doi.org/10.1186/1471-2334-13-466

14. Moyo SJ, Aboud S, Kasubi M, Lyamuya EF, Maselle SY (2010) Antimicrobial resistance among producers and non-producers of extended spectrum beta-lactamases in urinary isolates at a tertiary Hospital in Tanzania. BMC research notes 3:348. https://doi.org/10. 1186/1756-0500-3-348

15. Blomberg B, Manji KP, Urassa WK, Tamim BS, Mwakagile DSM, Jureen R et al (2007) Antimicrobial resistance predicts death in Tanzanian children with bloodstream infections: a prospective cohort study. BMC Infect Dis 7:1-14. https://oi.org/10.1186/14712334-7-43

16. Mshana SE, Matee M, Rweyemamu M (2013) Antimicrobial resistance in human and animal pathogens in Zambia, Democratic Republic of Congo. Mozambique and Tanzania : an urgent need of a sustainable surveillance system Annals of Clinical Microbiology and Antimicrobials 12:1. https://doi.org/10.1186/ 1476-0711-12-28

17. Meremo A, Mshana SE, Kidenya BR, Kabangila R, Peck R, Kataraihya JB (2012) High prevalence of non-typhoid Salmonella bacteraemia among febrile HIV adult patients admitted at a tertiary hospital. North-Western Tanzania International Archives of Medicine 5:1. https://doi.org/10.1186/1755-7682-5-28

18. Blomberg B, Mwakagile DSM, Urassa WK, Maselle SY, Mashurano M, Digranes A et al (2004) Surveillance of antimicrobial resistance at a tertiary hospital in Tanzania. BMC Public Health 4:45. https://doi.org/10.1186/1471-2458-4-45

19. Lonchel CM, Melin P (2013) Extended-spectrum $\beta$-lactamaseproducing Enterobacteriaceae in Cameroonian hospitals. Eur J 
Clin Microbiol Infect Dis 32:79-87. https://doi.org/10.1007/ s10096-012-1717-4

20. Muvunyi CM, Masaisa F, Bayingana C, Mutesa L, Musemakweri A, Muhirwa G et al (2011) Decreased susceptibility to commonly used antimicrobial agents in bacterial pathogens isolated from urinary tract infections in Rwanda: need for new antimicrobial guidelines. The American journal of tropical medicine and hygiene 84: 923-928. https://doi.org/10.4269/ajtmh.2011.11-0057

21. Lonchel CM, Meex C, Gangoué-Piéboji J, Boreux R, Assoumou M-CO, Melin P et al (2012) Proportion of extended-spectrum Blactamase-producing Enterobacteriaceae in community setting in Ngaoundere. Cameroon BMC infectious diseases 12:53. https:// doi.org/10.1186/1471-2334-12-53

22. Isendahl J, Turlej-Rogacka A, Manjuba C, Rodrigues A, Giske CG, Nauclér P (2012) Fecal carriage of ESBL-producing E. coli and K. pneumoniae in children in Guinea-Bissau: a hospital-based crosssectional study. PLoS One 7:e51981. https://doi.org/10.1371/ journal.pone.0051981

23. Feglo P, Adu-Sarkodie Y, Ayisi L, Jain R, Spurbeck RR, Springman $A C$ et al (2013) Emergence of a novel extended-spectrum- $\beta$ lactamase (ESBL)-producing, fluoroquinolone-resistant clone of extraintestinal pathogenic Escherichia coli in Kumasi, Ghana. J Clin Microbiol 51:728-730. https://doi.org/10.1128/JCM.03006-12

24. Obeng-Nkrumah N, Twum-Danso K, Krogfelt KA, Newman MJ (2013) High levels of extended-spectrum beta-lactamases in a major teaching hospital in Ghana: the need for regular monitoring and evaluation of antibiotic resistance. The American journal of tropical medicine and hygiene 89:960-964. https://doi.org/10.4269/ajtmh. $12-0642$

25. Von Wintersdorff CJH, Penders J, Stobberingh EE, Lashof AMLO, Hoebe CJPA, Savelkoul PHM et al (2014) High rates of antimicrobial drug resistance gene acquisition after international travel, the Netherlands. Emerg Infect Dis 20:649-657

26. Blomberg B, Jureen R, Manji KP, Tamim BS, Mwakagile DSM, Urassa WK et al (2005) High rate of fatal cases of pediatric septicemia caused by gram-negative bacteria with extended-spectrum beta-lactamases in Dar es Salaam, Tanzania. J Clin Microbiol 43: 745-749. https://doi.org/10.1128/JCM.43.2.745-749.2005

27. Ndugulile F, Jureen R, Harthug S, Urassa W, Langeland N (2005) Extended spectrum beta-lactamases among gram-negative bacteria of nosocomial origin from an intensive care unit of a tertiary health facility in Tanzania. BMC Infect Dis 5:86. https://doi.org/10.1186/ 1471-2334-5-86

28. Mshana SE, Kamugisha E, Mirambo M, Chakraborty T, Lyamuya EF (2009) Prevalence of multiresistant gram-negative organisms in a tertiary hospital in Mwanza. Tanzania. BMC research notes 2:49. https://doi.org/10.1186/1756-0500-2-49

29. Manyahi J, Matee MI, Majigo M, Moyo S, Mshana SE, Lyamuya EF (2014) Predominance of multi-drug resistant bacterial pathogens causing surgical site infections in Muhimbili National Hospital. Tanzania BMC research notes 7:500. https://doi.org/10.1186/ 1756-0500-7-500

30. Mshana SE, Falgenhauer L, Mirambo MM, Mushi MF, Moremi N, Julius R et al (2016) Predictors of blaCTX-M-15 in varieties of Escherichia coli genotypes from humans in community settings in Mwanza, Tanzania. BMC Infect Dis 16:1-9. https://doi.org/10. 1186/s12879-016-1527-x

31. Nelson E, Kayega J, Seni J, Mushi MF, Kidenya BR, Hokororo A et al (2014) Evaluation of existence and transmission of extended spectrum beta lactamase producing bacteria from post-delivery women to neonates at Bugando Medical Center. MwanzaTanzania BMC Research Notes 7:279. https://doi.org/10.1186/ 1756-0500-7-279

32. United Nations, Department of Economic and Social Affairs, Population Division (2015). World population prospects:The 2015 Revision, Key Findings and Advance Tables. Working
Paper No. ESA/P/WP.241. doi: https://doi.org/10.1017/ CBO9781107415324.004

33. García-Tello A, Gimbernat H, Redondo C, Arana DM, Cacho J, Angulo JC (2014) Extended-spectrum beta-lactamases in urinary tract infections caused by Enterobacteria: understanding and guidelines for action. Actas urologicas espanolas 38:678-684. https://doi. org/10.1016/j.acuro.2014.05.004

34. Sonda T, Kumburu H, van Zwetselaar M, Alifrangis M, Lund O, Kibiki G et al (2016) Meta-analysis of proportion estimates of extended-spectrum-beta-lactamase-producing Enterobacteriaceae in East Africa hospitals. Antimicrobial Resistance \& Infection Control 5:1-9. https://doi.org/10.1186/s13756-016-0117-4

35. Kumburu HH, Sonda T, Mmbaga BT, Alifrangis M, Lund O, Kibiki $\mathrm{G}$ et al (2017) Patterns of infections, aetiological agents and antimicrobial resistance at a tertiary care hospital in northern Tanzania. Trop Med Int Health 22:454-464. https://doi.org/10.1111/tmi. 12836

36. Illumina Inc. Nextera ${ }^{\circledR}$ XT Library Prep Reference Guide [Internet]. Sample Preparation Guide 2016;1-28. doi: http:/ support.illumina.com/downloads/nextera_xt_sample_preparation guide_15031942.html

37. Alabi AS, Frielinghaus L, Kaba H, Kösters K, Huson MAM, Kahl $\mathrm{BC}$ et al (2013) Retrospective analysis of antimicrobial resistance and bacterial spectrum of infection in Gabon. Central Africa BMC infectious diseases 13:455. https://doi.org/10.1186/1471-2334-13455

38. Bercion R, Mossoro-kpinde D, Manirakiza A, Le Faou A (2009) Increasing prevalence of antimicrobial resistance among Enterobacteriaceae uropathogens in Bangui, Central African Republic. Journal of infection in developing countries 3:187-190

39. Kajeguka DC, Nambunga PP, Kabissi F, Kamugisha B, Kassam N, Nyombi B et al (2015) Antimicrobial resistance patterns of phenotype extended spectrum beta-lactamase producing bacterial isolates in a referral hospital in northern Tanzania. Tanzania Journal of Health Research 17. https://doi.org/10.4314/thrb.v17i3.\%c

40. Zaki MES (2007) Extended spectrum beta-lactamases among gram-negative bacteria from an Egyptian pediatric hospital: a two-year experience. Journal of infection in developing countries 1:269-274

41. Buys H, Muloiwa R, Bamford C, Eley B (2016) Klebsiella pneumoniae bloodstream infections at a South African children's hospital 2006-2011, a cross-sectional study. BMC Infect Dis 16: 570. https://doi.org/10.1186/s12879-016-1919-y

42. Rodríguez-Baño J, Picón E, Gijón P, Hernández JR, Ruíz M, Peña $\mathrm{C}$ et al (2010) Community-onset bacteremia due to extendedspectrum beta-lactamase-producing Escherichia coli: risk factors and prognosis. Clinical infectious diseases : an official publication of the Infectious Diseases Society of America 50:40-48. https://doi. org/10.1086/649537

43. Tumbarello M, Spanu T, Sanguinetti M, Citton R, Montuori E, Leone $\mathrm{F}$ et al (2006) Bloodstream infections caused by extendedspectrum-beta-lactamase-producing Klebsiella pneumoniae: risk factors, molecular epidemiology, and clinical outcome. Antimicrob Agents Chemother 50:498-504. https://doi.org/10. 1128/AAC.50.2.498-504.2006

44. Ben-Ami R, Rodríguez-Baño J, Arslan H, Pitout JDD, Quentin C, Calbo ES et al (2009) A multinational survey of risk factors for infection with extended-spectrum beta-lactamase-producing enterobacteriaceae in nonhospitalized patients. Clinical infectious diseases : an official publication of the Infectious Diseases Society of America 49:682-690. https://doi.org/10.1086/604713

45. Cornejo-Juárez P, Pérez-Jiménez C, Silva-Sánchez J, VelázquezAcosta C, González-Lara F, Reyna-Flores F et al (2012) Molecular analysis and risk factors for Escherichia coli producing extended-spectrum $\beta$-lactamase bloodstream infection in 
hematological malignancies. PLoS One 7:e35780. https:/doi.org/ 10.1371/journal.pone.0035780

46. van den Boogaard J, Semvua HH, Boeree MJ, Aarnoutse RE, Kibiki GS (2009) Sale of fluoroquinolones in northern Tanzania: a potential threat for fluoroquinolone use in tuberculosis treatment. J Antimicrob Chemother 65:145-147. https://doi.org/10.1093/jac/ dkp413

47. Gwimile JJ, Shekalaghe SA, Kapanda GN, Kisanga ER (2012) Antibiotic prescribing practice in management of cough and/or diarrhoea in Moshi municipality. Northern Tanzania: cross-sectional descriptive study The Pan African medical journal 12:103

48. Thriemer K, Katuala Y, Batoko B, Alworonga J-P, Devlieger H, Van Geet $C$ et al (2013) Antibiotic prescribing in DR Congo: a knowledge, attitude and practice survey among medical doctors and students. PLoS One 8:e55495. https://doi.org/10.1371/journal. pone. 0055495
49. Al Yousef SA, Younis S, Farrag E, Moussa HS, Bayoumi FS, Ali AM (2016) Clinical and laboratory profile of urinary tract infections associated with extended spectrum B-lactamase producing Escherichia coli and Klebsiella pneumoniae. Ann Clin Lab Sci 46:393-400

50. Vardi M, Kochavi T, Denekamp Y, Bitterman H (2012) Risk factors for urinary tract infection caused by Enterobacteriaceae with extended-spectrum beta-lactamase resistance in patients admitted to internal medicine departments. Isr Med Assoc J 14:115-118

51. Park YS, Bae IK, Kim J, Jeong SH, Hwang S, Seo Y-H et al (2014) Risk factors and molecular epidemiology of community-onset extended-spectrum $\beta$-lactamase-producing Escherichia coli bacteremia. Yonsei Med J 55:467-475. https://doi.org/10.3349/ymj. 2014.55.2.467 